\title{
Article \\ Acute Changes in Thyroid Hormone Levels among Thai Pesticide Sprayers
}

\author{
Pornpimol Kongtip ${ }^{1,2, * \mathbb{D}}$, Noppanun Nankongnab ${ }^{1,2}{ }^{-1}$, Ritthirong Pundee ${ }^{3}$, Nichcha Kallayanatham ${ }^{1}$, \\ Sumate Pengpumkiat ${ }^{1}{ }^{1}$, Jutamanee Chungcharoen ${ }^{1}$, Chavisa Phommalachai ${ }^{1}$, Pajaree Konthonbut ${ }^{1}$, \\ Nattagorn Choochouy ${ }^{4}$, Preecha Sowanthip ${ }^{2}$, Phanthawee Khangkhun ${ }^{5}$, Jutharak Yimsabai ${ }^{6}$ and \\ Susan Woskie ${ }^{7}$ (D)
}

check for updates

Citation: Kongtip, P.; Nankongnab, N.; Pundee, R.; Kallayanatham, N.; Pengpumkiat, S.; Chungcharoen, J.; Phommalachai, C.; Konthonbut, P.; Choochouy, N.; Sowanthip, P.; et al. Acute Changes in Thyroid Hormone Levels among Thai Pesticide Sprayers. Toxics 2021, 9, 16. https://doi.org/ $10.3390 /$ toxics 9010016

Received: 5 December 2020

Accepted: 15 January 2021

Published: 19 January 202

Publisher's Note: MDPI stays neutral with regard to jurisdictional claims in published maps and institutional affiliations.

Copyright: (c) 2021 by the authors. Licensee MDPI, Basel, Switzerland. This article is an open access article distributed under the terms and conditions of the Creative Commons Attribution (CC BY) license (https:// creativecommons.org/licenses/by/ $4.0 /)$.
1 Department of Occupational Health and Safety, Faculty of Public Health, Mahidol University, 420/1 Rajvidhi Road, Bangkok 10400, Thailand; noppanun.nan@mahidol.ac.th (N.N.); nichcha.kal@gmail.com (N.K.); sumate.pen@mahidol.ac.th (S.P.); yiesipttt@gmail.com (J.C.); chawisa.ph8@gmail.com (C.P.); pajaree.kon@mahidol.ac.th (P.K.)

2 Center of Excellence on Environmental Health and Toxicology, EHT, Bangkok 10400, Thailand; preecha.sow@mahidol.ac.th

3 Nakhonsawan Campus, Mahidol University, Nakhonsawan 60130, Thailand; rtg.pun@gmail.com

4 Faculty of Public Health, Thammasat University Lampang Campus, Lampang 52190, Thailand. n.choochouy@gmail.com

5 Bureau of Elderly Health, Department of Health, Ministry of Public Health, Nonthaburi 11000, Thailand; phanthawee.kha@gmail.com

6 Department of Medical Technology and Clinical Pathology, Buddhachinaraj Phitsanulok Hospital, 90 Sithamma Traipidok Road, Muang, Phitsanulok 65000, Thailand; jutharak@gmail.com

7 Department of Public Health, University of Massachusetts Lowell, One University Ave, Lowell, MA 01854-2867, USA; Susan_Woskie@uml.edu

* Correspondence: pornpimol.kon@mahidol.ac.th; Tel.: +66-2644-4070; Fax: +66-2354-8561

\begin{abstract}
The objective of this study was to investigate the relationship of acute pesticide exposures and acute changes in thyroid hormones among Thai farmers. We recruited 78 farmers, who were scheduled to spray insecticides (chlorpyrifos and/or cypermethrin) or herbicides (paraquat and/or glyphosate). On the day before spraying, farmers collected their first morning void urine and went for blood collection. On the spray day, urine samples were collected at end of the spraying event and they were interviewed with questionnaires. The next morning, the first morning void urine and blood samples were collected. Blood samples were analyzed for thyroid hormones. Urine samples were analyzed for the metabolites of the pesticide sprayed. The results showed that the thyroid hormones, free triiodothyronine (FT3) and total triiodothyronine (T3) were significantly reduced as urinary chlorpyrifos metabolite increased the day after spraying. Total thyroxine (T4) significantly increased as cypermethrin metabolites increased the day after spraying. T4 significantly increased as urinary glyphosate levels increased; however, FT3 and T3 decreased significantly as urinary paraquat levels increased the day after spraying. These findings suggest that acute exposures to the pesticides chlorpyrifos, cypermethrin, paraquat and glyphosate can produce acute effects on the hypothalamic-pituitary-thyroid (HPT) axis, acutely altering thyroid hormone levels.
\end{abstract}

Keywords: cypermethrin; paraquat; glyphosate; chlorpyrifos; thyroid hormones; acute exposure; farmers; pesticides; endocrine disrupter

\section{Introduction}

Over 120 pesticides have been listed as potential endocrine-disrupting chemicals (EDCs) [1-3]. Many insecticides are considered EDCs, including organophosphates (OPs) such as chlorpyrifos-methyl and malathion, and pyrethroids such as cypermethrin, deltamethrin and permethrin. Some herbicides are also considered EDCs, including glyphosate and atrazine [1]. EDCs can impact the hypothalamic-pituitary-thyroid (HPT) axis and 
alter thyroid hormone levels by disrupting central regulation, iodine uptake, production and distribution of thyroid hormones, or binding of the thyroid hormones to membrane transporters or receptors [4-6].

Currently, OPs remain one of the most commonly used pesticides [7]. Several epidemiologic studies have established an association between OPs and alterations of thyroid hormone levels $[8,9]$. A limited number of studies have examined whether ever using OP pesticides was associated with hypothyroidism [9-11], or whether use in the past growing season was related to alterations in thyroid hormone levels [12-14]. Experimental animal studies have also shown that organophosphate (OP) disturb thyroid gland function $[15,16]$. Whether the thyroid effects are caused by the parent OPs or the DAP metabolites is not known [7]. When humans are exposed to the OP, it is metabolized into the specific metabolite 3,5,6-trichloro-2-pyridinol (TCP) and the nonspecific OP metabolites diethyl phosphate (DEP) and diethyl thiophosphate (DETP) $[17,18]$.

Synthetic pyrethroids are insecticides that have been introduced over the past two decades for agricultural and domestic use [19]. Pyrethroids are widely used in agriculture, animal husbandry and in homes to control insect pests (ants, cockroaches, mosquitos) [20,21]. Cypermethrin, a synthetic pyrethroid, was found to induce neurotoxicity in animal studies through free radical formation, reduction in the antioxidant defense mechanism, and inhibition of acetylcholinesterase (AChE) activity [22]. Pyrethroids also exhibit endocrine disrupting properties [1,23,24], and may impact fertility [25]. Human studies of thyroid hormone levels related to pyrethroid exposure have been inconclusive to date, in part due to low exposures [24] or mixed pesticide exposures [26].

Glyphosate herbicides are widely used in agricultural areas in Thailand. In plants, glyphosate acts through inhibition of the shikimate metabolic pathway [27]. Acute intoxication of humans by glyphosate can cause hypotension, tachycardia, renal failure, respiratory distress, metabolic acidosis, and electrolyte imbalances [28]. Glyphosate is not readily metabolized in the human body, and thus the parent compound can be measured in urine. There is mixed evidence regarding the impact of glyphosate on the thyroid. The U.S. Agricultural Health study has reported that among pesticide applicators, self-reported use of glyphosate is associated with hypothyroidism [9]. However, subsequent studies in the same cohort did not confirm this finding [11,29].

For paraquat, acute poisoning can result in lung damage, pneumonitis and lung fibrosis, renal and liver injury, acute renal failure, respiratory failure, and mucosal injury. Due to its high acute toxicity and adverse effects on human health, paraquat is now banned in over 50 countries including the 27 countries of the European Union, Cambodia, China, Vietnam, and Thailand [30-32]. Information on the effect of paraquat on thyroid function is limited to agricultural populations in Brazil [33].

The thyroid plays an important role in metabolism, thermogenesis, immunity, and aging and changes in thyroid hormone production with age is associated with changes in other organs and systems [34]. Franceschi et al. proposed the concept of "thyroid biography" to cover the combination of factors that impact thyroid function over the lifespan, including genetics, exposure to endocrine disruptors and lifestyle habits [34]. Changes in thyroid status with age are in turn associated with cognitive and functional status and mortality [35]. We have previously shown in the larger longitudinal cohort, from which the farmers in this study were recruited, that after adjusting for covariates, thyroid hormone levels of conventional pesticide using farmers were significantly higher than those of organic farmers. Several specific herbicides had a significant relationship between the amount applied and an increase in thyroid hormone levels [12], and increasing the cumulative number of spray days of pesticides significantly increases the level of thyroid stimulating hormone (TSH) and free triiodothyronine (FT3) [13]. These farmers also had significantly higher abnormal metabolic biomarkers, body mass index (BMI), waist circumference, \% body fat, triglycerides, total cholesterol, and low-density lipoprotein (LDL) values) compared to the organic farmers [36], and there was a significant association between the number of days of pesticide spraying and levels of cholesterol, high-density 
lipoprotein (HDL), LDL, blood pressure and BMI in the longitudinal cohort [37]. These findings support the proposal that pesticides may function as endocrine disrupters, in part through the HPT axis, increasing the risk for abnormal metabolic biomarkers which are linked to the development of long term metabolic disease (Cardiovacular disease, stroke, diabetes). Nevertheless, how repeated acute exposures to pesticides can result in these chronic health effects has not been clearly demonstrated.

Like our previous work, most of the human studies related to the effects of pesticides on thyroid hormones refer to longer term chronic exposures and often involve exposures to many types of pesticides including insecticides, herbicides, and fungicides. We did find one study in India that examined the effect of acute poisoning from organophosphate compounds on the thyroid profile of individuals. The results showed that $\mathrm{T} 4$ was significantly higher in the acute poisoning phase and went down after a one-month recovery, while TSH and T3 were significantly reduced in the acute poisoning phase and then returned to normal after recovery [38].

This study was designed to investigate the relationship of acute pesticide exposures and acute changes in thyroid hormones among Thai farmers. We measured farmer's exposure (change in metabolite levels) to chlorpyrifos or cypermethrin insecticides, paraquat or glyphosate herbicides from the day before to the day after spraying along with changes in levels of thyroid hormones from the day before to the day after spraying.

\section{Materials and Methods}

\subsection{Study Population and Data Collection}

Data collection for this study (November 2016 to January 2019), was approved by the Ethical Review Committee for Human Research, Faculty of Public Health, Mahidol University (Approval No. MUPH 2015-146, date of approval: (28 August 2015). Informed consent was obtained from all participants. From our larger longitudinal study of conventional (pesticide using) and organic farmers $(n=438)$, we recruited seventy-eight sugarcane farmers from Khao Thong Subdistrict, Phayuha Khiri District in Nakornsawan province, in the upper central area in Thailand. We selected one farmer who sprayed pesticides in each family. They were male or female over 18 years old, free of a current diagnosis of diabetes, high blood pressure, and thyroid or heart disease. The field staff set an appointment with the farmers when they planned to spray chlorpyrifos, cypermethrin, paraquat or glyphosate in their fields. Most of the farmers sprayed one pesticide at a time and some participated on multiple days when they sprayed other targeted pesticides. Some of the farmers mixed other chemicals in with the targeted pesticides. The farmers spraying one chemical per day were $91.7 \%$ for glyphosate, $83.3 \%$ for cypermethrin, $45.1 \%$ for chlorpyrifos and $33.3 \%$ for paraquat; the rest of each group mixed with other chemicals such as acetochlor, 2,4 D, amethrin, diuron, etc. They sometimes mixed with 1-2 pesticides to save time and cost of spraying. Before the spraying day, urine samples were collected at waking, as first morning void and stored in an insulated carrier with ice to bring to the nearby clinic, where blood samples were collected between 7-9 a.m., and subjects were interviewed. The questionnaire covered home and demographic information, agricultural activities, history of pesticide mixing and spraying, use of personal protective equipment, acute health symptoms after spraying pesticides and a measure of self-reported stress that covered sleeping problems, reduced concentration, irritation, boredom, and lack of interest in meeting people. On the spray day, the field staff observed the spraying and interviewed the subject about the amount of pesticide used and the subject provided a urine sample at the end of the spraying event. The next day, the subject collected a first morning void urine and again came to the clinic between 7-9 a.m. for blood collection. The blood samples were used for thyroid hormone measurements. Urine samples were analyzed for biomarkers of exposure (metabolites of the sprayed pesticides). 


\subsection{Blood Analysis}

Sera extracted from blood samples in non-heparinized vacutainer tubes were stored at $-20{ }^{\circ} \mathrm{C}$ until analysis. All samples were analyzed at Buddhachinaraj Hospital, the regional medical center in Phitsanulok province using standard clinical laboratory methods. Analysis of thyroid hormones using a paramagnetic particle, chemiluminescent immunoassay for the quantitative determination of TSH, FT3, free thyroxine (FT4), total triiodothyronine (T3), and total thyroxine (T4) in human serum using the UniCel DxI 800 Access Immunoassay System, Beckman Coulter (Atlanta, GA, USA) [12]. The limit of detection was $0.005 \mu \mathrm{IU} / \mathrm{mL}$ for TSH, $0.09 \mathrm{ng} / \mathrm{dL}$ for FT3, $0.15 \mathrm{ng} / \mathrm{dL}$ for FT4, $0.01 \mu \mathrm{g} / \mathrm{dL}$ for T3 and $0.5 \mu \mathrm{g} / \mathrm{dL}$ for T4.

\subsection{Urine Sample Analysis}

Urine samples from chlorpyrifos-spraying farmers were analyzed for TCP $(3,5,6-$ trichloro-2-pyridinol), the specific metabolite of chlorpyrifos using gas chromatographymass spectrometry (GC-MS), the detection limit of TCP in urine was $1 \mathrm{ng} / \mathrm{mL}$ [39].

The analysis of the non-specific OP metabolites of chlorpyrifos diethylphosphate (DEP) and diethylthiophosphate (DETP), used the GC-MS method of Prapamontol et al., (2014) [40] except that the derivatization with 2,3,4,5,6-Pentafluorobenzyl bromide was conducted at $80{ }^{\circ} \mathrm{C}$ for $1.5 \mathrm{~h}$. The recovery of a mixed DEP and DETP standard of 250 and $750 \mathrm{ng} / \mathrm{mL}$ ranged from $97-101 \%$ with relative standard deviation (RSD) of less than $10 \%$. The detection limit of the DEP and DETP was 4.53 and $5.12 \mathrm{ng} / \mathrm{mL}$, respectively. The results presented used total DEP(TDEP $)=$ DEP + DETP.

Urine samples from cypermethrin-spraying farmers were analyzed for 3-phenoxybenzoic acid (3PBA) and cis-3-(2,2-dichlorovinyl)-2,2-dimethylcyclopropane-1-carboxylic acid, trans-3-(2,2-dichlorovinyl)-2,2-dimethylcyclopropane-1-carboxylic ac-id (cis, trans-DCCA) using GC-MS, following the method of Singleton et al. (2014) [41]. The recovery of 3PBA and cis, trans-DCCA concentrations of 25, 100 and $150 \mathrm{ng} / \mathrm{mL}$ ranged from $97.86-101.04 \%$ with RSD less than $6 \%$. The results were presented as total cypermethrin metabolites(Tcyper) $=3 \mathrm{BPA}+$ cis, trans -DCCA.

Urine samples from paraquat- and glyphosate-spraying farmers were analyzed for paraquat [42] and glyphosate [43] using high-pressure liquid chromatography with fluorescent detector. The recovery of urinary paraquat for between-day was $95.83 \%$ and $96.52 \%$ and RSD was $3.13 \%$ and $4.04 \%$ for 30 and $80 \mathrm{ng} / \mathrm{mL}$ paraquat in urine, respectively with the detection limit of $1 \mathrm{ng} / \mathrm{mL}$. The accuracy of glyphosate in urine was 76.88 and $98.40 \%$ and RSD was 3.26 and 2.85 at concentrations of 20 and $100 \mathrm{ng} / \mathrm{mL}$ with the detection limit of $1 \mathrm{ng} / \mathrm{mL}$. For concentrations below the detection limit, we substituted the detection limit by dividing the detection with 2 for GSD $<3$ or the detection limit divided by two for GSD $\geq 3$ [44]. All urinary metabolites were creatinine corrected (per gram creatinine). The creatinine in urine was analyzed using an enzymatic method with a linear concentration range of $1-500 \mathrm{mg} / \mathrm{dL}$ and a detection limit $0.16 \mathrm{mg} / \mathrm{dL}$ [45].

\subsection{Statistical Analysis}

All statistical analyses were done by SPSS for Windows, version 23 (IBM Thailand Co., Ltd., Bangkok, Thailand). Descriptive analysis of the demographic characteristics was done using Chi Square, Fisher's exact test and independent $t$-tests. Due to the skewed distribution of the thyroid hormone and pesticide urinary metabolite data, the natural logarithm was used in all analyses. The natural log values for the urinary metabolite concentrations for the day before spraying, end of spraying task and the next day after spraying were compared using a repeated measure ANOVA. Natural log thyroid levels on the day before and the next day after spraying were compared using a paired $t$ test. The model for change in thyroid hormone levels was performed using a generalized linear model. For each thyroid hormone, we developed a multivariable generalized linear model for change in the thyroid hormone level (logged morning after spraying-logged morning before spraying) as a function of the change in the urinary metabolite level for a specific 
pesticide (logged morning after spraying-logged morning before spraying). Additional covariates for each model were considered based on their significance in univariate analyses. In our previous cross-sectional study, we included gender, current smoking, current alcohol use, insecticide use at home in the past year, triglyceride levels and any stress symptoms in the past 2-4 weeks [12], so we examined these covariates in our univariate models. Others have also included socioeconomic status $[46,47]$ in their work, so we also examined education and debt status in univariate models.

\section{Results}

The average age of farmers was 49.6 years and they were mainly male (74.4\%) (Table 1$)$.

Table 1. Demographic characteristics of conventional farmers $(n=78)$ spraying chlorpyrifos, cypermethrin, glyphosate or paraquat.

\begin{tabular}{|c|c|}
\hline Variables & $n(\%)$ \\
\hline \multicolumn{2}{|l|}{ Age } \\
\hline Min-max & $18-69$ \\
\hline Mean (SD) & $49.6(12.3)$ \\
\hline \multicolumn{2}{|l|}{ Sex } \\
\hline Male & $58(74.4)$ \\
\hline Female & $20(25.6)$ \\
\hline \multicolumn{2}{|l|}{ Educational level } \\
\hline Elementary & $34(44.2)$ \\
\hline High school & $42(54.5)$ \\
\hline Bachelor or higher & $1(1.3)$ \\
\hline \multicolumn{2}{|l|}{ Marital status } \\
\hline Single & $10(13.5)$ \\
\hline Married & $62(83.8)$ \\
\hline Widowed/divorced & $2(2.8)$ \\
\hline \multicolumn{2}{|l|}{ Expense adequacy } \\
\hline Enough for saving & $6(7.7)$ \\
\hline Just enough & $(46.2)$ \\
\hline In debt & $36(46.2)$ \\
\hline \multicolumn{2}{|c|}{ Agricultural work time (h/week) } \\
\hline Mean (SD) & $27.5(9.5)$ \\
\hline \multicolumn{2}{|l|}{ Have Second Job } \\
\hline Number & $40(51.3)$ \\
\hline \multicolumn{2}{|l|}{ Second job work time (h/week) } \\
\hline Mean (SD) & $20.9(10.3)$ \\
\hline
\end{tabular}

Most had graduated from high school (54.5\%); $83.8 \%$ were married and $46.2 \%$ were in debt. More than half had a second job (51.3\%) such as working in a hair salon, vehicle repair shop, food stand, grocery store, or construction site. Most reported drinking alcohol $(66.7 \%)$, though few were current smokers (19.2\%). Most reported having symptoms of stress $(76.9 \%)$ in the past $2-4$ weeks (Table 2$)$. These farmers grew sugarcane $(98.7 \%)$ and rice $(83.3 \%)$, lived near $(<1 \mathrm{~km})$ their farmland $(94.9 \%)$ and almost all $(98.7 \%)$ used pesticides in their home.

For chlorpyrifos-spraying farmers, there was $100 \%$ detection for all time periods for urinary TCP. The $\log (\mathrm{e})$ of urinary TCP concentrations at the end of spraying and the next day after spraying were significantly higher from the day before spraying, and the urinary TCP concentrations at the end of the spraying event was also significantly lower than the next day after spraying (Table 3). There was also $100 \%$ detection for all time periods for urinary DEP and DETP, the non-specific OP metabolites of chlorpyrifos. The log(e) of urinary TDEP concentrations at the end of spraying and the next day after spraying were not significantly different from those the day before spraying, although the urinary TDEP concentrations at the end of the spraying event and the next day after spraying were significantly different (Table 3). 
Table 2. Risk factors and spraying factors of conventional farmers $(n=78)$ spraying chlorpyrifos, cypermethrin, paraquat and glyphosate.

\begin{tabular}{|c|c|}
\hline Risk Factors & $n(\%)$ \\
\hline \multicolumn{2}{|l|}{ Alcohol intake } \\
\hline Current drinker & $52(66.7)$ \\
\hline Not current drinker & $26(33.3)$ \\
\hline \multicolumn{2}{|l|}{ Smoking } \\
\hline Current smoker & $15(19.2)$ \\
\hline Not current smoker & $63(80.8)$ \\
\hline \multicolumn{2}{|l|}{ Heavy exercise in past month } \\
\hline Yes & $25(32.1)$ \\
\hline No & $53(67.9)$ \\
\hline \multicolumn{2}{|l|}{ Stress in past 2-4 weeks } \\
\hline Yes & $60(76.9)$ \\
\hline Almost Never & $18(23.1)$ \\
\hline \multicolumn{2}{|l|}{ Years of pesticide use } \\
\hline Mean (SD) & $25.0(14.4)$ \\
\hline \multicolumn{2}{|l|}{ Living near farm $(1 \mathrm{~km})$} \\
\hline Yes & $74(94.9)$ \\
\hline No & $4(5.1)$ \\
\hline \multicolumn{2}{|l|}{ Insecticide use in home } \\
\hline Yes & $77(98.7)$ \\
\hline No & $1(1.3)$ \\
\hline \multicolumn{2}{|l|}{ Types of crop } \\
\hline Rice & $65(83.3)$ \\
\hline Sugarcane & $77(98.7)$ \\
\hline others & $41(52.6)$ \\
\hline Other parameters & Mean (SD) \\
\hline Triglyceride & $147.6(122.5)$ \\
\hline $\operatorname{BMI}\left(\mathrm{kg} / \mathrm{m}^{2}\right)$ & $25.5(6.4)$ \\
\hline \multicolumn{2}{|l|}{ Amount of time spraying (min) } \\
\hline Chlorpyrifos & $37.8(21.5)$ \\
\hline Cypermethrin & $49.3(37.7)$ \\
\hline Paraquat & $61.0(31.1)$ \\
\hline Glyphosate & $37.4(20.8)$ \\
\hline \multicolumn{2}{|l|}{ Volume of pesticide spray (L) } \\
\hline Chlorpyrifos & $88.4(81.3)$ \\
\hline Cypermethrin & $194.0(257.2)$ \\
\hline Paraquat & $394.8(392.1)$ \\
\hline Glyphosate & $79.6(59.1)$ \\
\hline \multicolumn{2}{|l|}{ Size of area sprayed (Rai) } \\
\hline Chlorpyrifos & $2.9(2.1)$ \\
\hline Cypermethrin & $5.3(3.8)$ \\
\hline Paraquat & $5.9(3.5)$ \\
\hline Glyphosate & $2.2(1.5)$ \\
\hline
\end{tabular}

For cypermethrin-spraying farmers, there was $100 \%$ detection for all farmers at all time periods for 3PBA and TCyper, however urinary cis, trans-DCCA concentrations were detected in $68.1 \%$ (day before), $83 \%$ (after spraying) and $74.5 \%$ (next day) of the farmers. The $\log (\mathrm{e})$ of urinary 3PBA concentrations at the end of spraying and the next day after spraying were significantly higher than those the day before spraying, but the urinary 3PBA concentrations at the end of the spraying event and the next day after spraying were not significantly different. The $\log (\mathrm{e})$ of the urinary cis, trans-DCCA concentrations at the end of spraying and the next day after spraying were significantly higher than those the day before spraying, but the urinary 3PBA concentrations at the end of the spraying event and the next day after spraying were not significantly different. The $\log (\mathrm{e})$ of the urinary TCyper levels had a similar pattern to that of 3PBA. 
Table 3. Urinary metabolite concentrations at three time points for pesticide sprayers: morning void urine the day before spraying, end of spraying activity, morning void urine the day after spraying.

\begin{tabular}{|c|c|c|c|c|c|}
\hline \multirow{2}{*}{$\begin{array}{c}\text { Urinary } \\
\text { Metabolites }\end{array}$} & \multicolumn{2}{|c|}{ Sprayed Chlorpyrifos } & \multicolumn{3}{|c|}{ Sprayed Cypermethrin } \\
\hline & $\begin{array}{c}\text { TCP }(n=51) \\
\text { ( } \mu \mathrm{g} / \mathrm{g} \text { Creatinine })\end{array}$ & $\begin{array}{c}\text { TDEP }(n=47) \\
\text { (nmol/g Creatinine) }\end{array}$ & $\begin{array}{c}\text { 3PBA }(n=47) \\
\text { (nmol/g Creatinine) }\end{array}$ & $\begin{array}{c}\text { DCCA }(n=47) \\
\text { (nmol/g Creatinine) }\end{array}$ & $\begin{array}{c}\text { TCyper }(n=47) \\
(\text { nmol/g Creatinine) }\end{array}$ \\
\hline \multicolumn{6}{|c|}{ First morning urine on day before spraying } \\
\hline $\begin{array}{c}\text { Detection } \\
\text { frequency }(\%)\end{array}$ & $51(100)$ & 47 (100) & 47 (100) & $32(68.1)$ & 47 (100) \\
\hline (1) GM (GSD) & $4.31(2.93)$ & $458.38(3.48)$ & $82.32(1.87)$ & $18.61(2.17)$ & $108.56(1.73)$ \\
\hline Range & $0.4-139.8$ & $54.1-6634.2$ & $21.54-311.06$ & $5.81-106.70$ & $37.71-323.76$ \\
\hline \multicolumn{6}{|c|}{ Urine at the end of spraying event } \\
\hline $\begin{array}{c}\text { Detection } \\
\text { frequency }(\%)\end{array}$ & $51(100)$ & $47(100)$ & 47 (100) & $39(83.0)$ & 47 (100) \\
\hline (2) GM (GSD) & $7.79(3.39)$ & $346.99(4.05)$ & $149.35(2.02)$ & $29.12(2.01)$ & $190.01(1.81)$ \\
\hline Range & $0.3-164.0$ & $21.5-7044.5$ & $43.38-533.79$ & $4.53-129.02$ & $58.56-584.06$ \\
\hline \multicolumn{6}{|c|}{ First morning urine the next day after spraying } \\
\hline $\begin{array}{c}\text { Detection } \\
\text { frequency (\%) }\end{array}$ & $51(100)$ & 47 (100) & $47(100)$ & $35(74.5)$ & 47 (100) \\
\hline (3) GM (GSD) & $14.06(2.34)$ & $540.61(3.10)$ & $169.93(1.88)$ & $30.53(2.42)$ & $212.98(1.76)$ \\
\hline Range & $2.41-141.20$ & $51.42-7863.60$ & $49.90-828.82$ & $5.70-162.39$ & 75.19-992.27 \\
\hline \multicolumn{6}{|c|}{ Paired comparisons of time points } \\
\hline$p$ value from & $(1)-(2) p=0.002$ & $(1)-(2) p=0.234$ & $(1)-(2) p<0.001$ & $(1)-(2) p<0.001$ & $(1)-(2) p<0.001$ \\
\hline repeated measures & (1) $-(3) p<0.001$ & (1)-(3) $p=0.421$ & (1) $-(3) p<0.001$ & (1)-(3) $p<0.001$ & $(1)-(3) p<0.001$ \\
\hline ANOVA on $\ln$ values & $(2)-(3) p<0.001$ & $(2)-(3) p=0.008$ & (2)-(3) $p=0.108$ & $(2)-(3) p=0.710$ & (2)-(3) $p=0.132$ \\
\hline
\end{tabular}

TCP $=$ Specific metabolite of chlorpyrifos; TDEP = DEP + DETP; TCyper = 3PBA + DCCA.

Urinary paraquat was detected in $62.7 \%$ (day before), $94.1 \%$ (after spraying) and $76.5 \%$ (next day) of the farmers (Table 4). The $\log (\mathrm{e})$ of urinary paraquat concentrations at the end of spraying and the next day after spraying were significantly higher than those the day before spraying, and the urinary paraquat concentrations at the end of the spraying event were also significantly higher than the concentrations the next day after spraying.

Table 4. Urinary metabolite concentrations of paraquat and glyphosate at three time points for pesticide sprayers: morning void urine the day before spraying, end of spraying activity, morning void urine the day after spraying.

\begin{tabular}{|c|c|c|}
\hline Parameter & $\begin{array}{l}\text { Paraquat }(n=51) \\
\text { ( } \mu \text { g/g Creatinine) }\end{array}$ & $\begin{array}{c}\text { Glyphosate }(n=48) \\
(\mu \mathrm{g} / \mathrm{g} \text { Creatinine })\end{array}$ \\
\hline \multicolumn{3}{|c|}{ First morning urine on day before spraying } \\
\hline Detection frequency $(\%)$ & $32(62.7)$ & $48(100)$ \\
\hline (1) GM (GSD) & $1.80(2.74)$ & $23.36(2.61)$ \\
\hline Range & $0.30-10.68$ & $3.05-138.07$ \\
\hline \multicolumn{3}{|l|}{ Urine at the end of spraying event } \\
\hline Detection frequency $(\%)$ & $48(94.1)$ & $48(100)$ \\
\hline (2) GM (GSD) & $5.96(2.59)$ & $39.90(2.54)$ \\
\hline Range & $0.34-46.51$ & $6.15-195.62$ \\
\hline \multicolumn{3}{|c|}{ First morning urine the next day after spraying } \\
\hline Detection frequency $(\%)$ & $39(76.5)$ & $48(100)$ \\
\hline (3) GM (GSD) & $2.99(3.09)$ & $48.47(2.62)$ \\
\hline Range & $0.41-124.2$ & $5.02-321.56$ \\
\hline \multicolumn{3}{|l|}{ Paired comparison of time points } \\
\hline & $(1)-(2) p<0.001$ & $(1)-(2) p<0.001$ \\
\hline$p$ value from repeated measures & (1)-(3) $p=0.016$ & (1)-(3) $p<0.001$ \\
\hline ANOVA on ln values & $(2)-(3) p=0.001$ & $(2)-(3) p=0.194$ \\
\hline
\end{tabular}

Urinary glyphosate was detected in $100 \%$ of the farmers in all time periods. The log(e) of the urinary glyphosate concentrations at the end of spraying and the next day after spraying were significantly higher than those the day before spraying, but the urinary 
glyphosate concentrations at the end of the spraying event and the next day after spraying were not significantly different.

With regard to thyroid hormones, the thyroid hormone levels on the day after spraying chlorpyrifos were significantly higher for FT4 and borderline higher for FT3, but the change in thyroid hormone levels from the day before to the day after spraying cypermethrin, paraquat or glyphosate were not significantly different (Tables 5 and 6). We did not get different results for the simple paired analysis of the change in thyroid hormone levels for cypermethrin, paraquat or glyphosate when stratified by gender. However, for chlorpyrifos male farmers showed significantly higher FT4 and FT3 the day after spraying $(p<0.001$ and $p=0.047, n=37$ ), while for female farmers there was only a borderline significant increase for T3 $(p=0.050, n=14)$.

Table 5. Comparison between thyroid hormones on the day before and the day after spraying insecticides chlorpyrifos and cypermethrin.

\begin{tabular}{|c|c|c|c|c|c|c|c|}
\hline & & \multicolumn{3}{|c|}{ Sprayed Chlorpyrifos $(n=51)$} & \multicolumn{3}{|c|}{ Sprayed Cypermethrin $(n=48)$} \\
\hline \multicolumn{2}{|c|}{ Thyroid Hormone } & Before & After & $p$-Value ${ }^{a}$ & Before & After & $p$-Value ${ }^{\text {a }}$ \\
\hline $\begin{array}{c}\text { TSH } \\
(\mu \mathrm{IU} / \mathrm{mL})\end{array}$ & $\begin{array}{c}\text { GM (GSD) } \\
\text { Range }\end{array}$ & $\begin{array}{c}1.44(1.99) \\
0.15-8.6\end{array}$ & $\begin{array}{c}1.51(1.76) \\
0.32-7.88\end{array}$ & 0.551 & $\begin{array}{c}1.55(1.66) \\
0.53-7.85\end{array}$ & $\begin{array}{l}1.51(1.99) \\
0.15-5.87\end{array}$ & 0.660 \\
\hline FT3 & GM (GSD) & $0.29(1.18)$ & $0.30(1.18)$ & \multirow[b]{2}{*}{0.056} & $0.29(1.15)$ & $0.29(1.12)$ & \multirow[b]{2}{*}{0.625} \\
\hline (ng/dL) & Range & $0.21-0.65$ & $0.20-0.60$ & & $0.19-0.40$ & $0.22-0.41$ & \\
\hline FT4 & GM (GSD) & $0.92(1.17)$ & $0.97(1.17)$ & \multirow{2}{*}{$0.002^{*}$} & $0.99(1.16)$ & $0.99(1.12)$ & \multirow{2}{*}{0.990} \\
\hline (ng/dL) & Range & $0.7-1.33$ & $0.7-1.51$ & & $0.71-1.34$ & $0.80-1.39$ & \\
\hline T3 & GM (GSD) & $0.90(1.23)$ & $0.86(1.24)$ & \multirow{2}{*}{0.073} & $0.84(1.27)$ & $0.86(1.24)$ & \multirow{2}{*}{0.541} \\
\hline$(\mu \mathrm{g} / \mathrm{dL})$ & Range & $0.59-1.88$ & $0.57-1.43$ & & $0.51-1.62$ & $0.53-1.45$ & \\
\hline $\mathrm{T} 4$ & GM (GSD) & $8.14(1.22)$ & $7.94(1.24)$ & \multirow{2}{*}{0.265} & $8.05(1.18)$ & $7.82(1.19)$ & \multirow{2}{*}{0.069} \\
\hline$(\mu \mathrm{g} / \mathrm{dL})$ & Range & $4.8-12.43$ & $4.55-12.35$ & & $5.47-11.25$ & $5.10-12.06$ & \\
\hline
\end{tabular}

a $t$-test on $\ln$ of paired thyroid hormone levels before spraying to after spraying; ${ }^{*}=$ Significant at $p<0.05$.

Table 6. Comparison between thyroid hormones on the day before and the day after spraying herbicides paraquat and glyphosate.

\begin{tabular}{|c|c|c|c|c|c|c|c|}
\hline & & \multicolumn{3}{|c|}{ Sprayed Paraquat $(n=51)$} & \multicolumn{3}{|c|}{ Sprayed Glyphosate $(n=48)$} \\
\hline \multicolumn{2}{|c|}{ Thyroid Hormone } & $\begin{array}{c}\text { Before } \\
\text { Spraying }\end{array}$ & $\begin{array}{c}\text { After } \\
\text { Spraying }\end{array}$ & $p$-Value ${ }^{\mathrm{a}}$ & $\begin{array}{c}\text { Before } \\
\text { Spraying }\end{array}$ & $\begin{array}{c}\text { After } \\
\text { Spraying }\end{array}$ & $p$-Value ${ }^{a}$ \\
\hline TSH & GM (GSD) & $1.30(2.07)$ & $1.21(1.90)$ & \multirow{2}{*}{0.490} & $1.30(2.07)$ & $1.21(1.90)$ & \multirow{2}{*}{0.426} \\
\hline$(\mu \mathrm{IU} / \mathrm{mL})$ & Range & $0.16-6.4$ & $0.23-6.48$ & & $0.14-4.44$ & $0.14-6.94$ & \\
\hline FT3 & GM (GSD) & $0.30(1.14)$ & $0.31(1.12)$ & \multirow{2}{*}{0.203} & $0.30(0.05)$ & $0.30(0.04)$ & \multirow{2}{*}{0.674} \\
\hline$(\mathrm{ng} / \mathrm{dL})$ & Range & $0.24-0.44$ & $0.23-0.39$ & & $0.21-0.39$ & $0.22-0.40$ & \\
\hline FT4 & GM (GSD) & $0.95(1.16)$ & $0.96(1.15)$ & \multirow{2}{*}{0.357} & $1.00(0.18)$ & $0.98(0.17)$ & \multirow{2}{*}{0.409} \\
\hline$(\mathrm{ng} / \mathrm{dL})$ & Range & $0.75-1.44$ & $0.76-1.4$ & & $0.65-1.55$ & $0.67-1.46$ & \\
\hline T3 & GM (GSD) & $0.89(1.26)$ & $0.93(1.24)$ & \multirow{2}{*}{0.078} & $0.89(0.20)$ & $0.89(0.15)$ & \multirow{2}{*}{0.978} \\
\hline$(\mu \mathrm{g} / \mathrm{dL})$ & Range & $0.56-1.74$ & $0.58-1.48$ & & $0.39-1.26$ & $0.59-1.26$ & \\
\hline $\mathrm{T} 4$ & GM (GSD) & $7.99(1.20)$ & $7.80(1.17)$ & \multirow{2}{*}{0.274} & 7.75 (1.33) & $7.99(1.58)$ & \multirow{2}{*}{0.202} \\
\hline$(\mu \mathrm{g} / \mathrm{dL})$ & Range & 5.16-11.86 & $5.51-11.32$ & & $5.16-11.30$ & $5.18-11.27$ & \\
\hline
\end{tabular}

a $t$-test on $\ln$ of paired thyroid hormone levels before spraying to after spraying; ${ }^{*}=$ Significant at $p<0.05$.

The models for change in thyroid hormone levels as a function of the change in urinary metabolite levels when spraying each specific pesticide showed that FT3 and T3, were significantly reduced as a function of the change per one $\mu \mathrm{g} / \mathrm{g}$ creatinine LnTCP (Table 7). For cypermethrin-spraying farmers, there was a significant increase in $\mathrm{T} 4$ as a function of the change per one nmol/g creatinine LnDCCA (Table 8). For the herbicide paraquat, FT3 and T3 were significantly reduced as a function of the change per one $\mu \mathrm{g} / \mathrm{g}$ creatinine LnParaquat (Table 9). However, the herbicide glyphosate showed a significant increase in $\mathrm{T} 4$ as a function of the change per one $\mu \mathrm{g} / \mathrm{g}$ creatinine LnGlyphosate. 
Table 7. Model for change in thyroid hormone levels (logged morning after spraying-logged morning before spraying) as a function of the change in urinary metabolite levels for sprayed insecticide chorpyrifos (logged morning after sprayinglogged morning before spraying).

\begin{tabular}{|c|c|c|c|c|c|c|}
\hline \multirow{2}{*}{$\Delta$ LNthyroid Hormones } & \multicolumn{3}{|c|}{$\begin{array}{c}\Delta \mathrm{LNTCP} \\
(\mu \mathrm{g} / \mathrm{g} \text { Creatinine })\end{array}$} & \multicolumn{3}{|c|}{$\begin{array}{c}\Delta \text { LNTDEP } \\
\text { (nmol/g Creatinine) }\end{array}$} \\
\hline & B & Standard Error & $p$-Value & B & Standard Error & $p$-Value \\
\hline$\Delta \mathrm{LNTSH}(\mathrm{nIU} / \mathrm{mL})$ & 1.2 & 78.6 & 0.988 & 41.1 & 64.1 & 0.521 \\
\hline$\triangle \mathrm{LNFT3}(\mathrm{pg} / \mathrm{dL})$ & -27.0 & 12.7 & $0.033 *$ & -0.16 & 12.7 & 0.990 \\
\hline$\Delta \mathrm{LNFT} 4(\mathrm{pg} / \mathrm{dL})$ & 9.1 & 14.3 & 0.526 & 14.5 & 9.5 & 0.128 \\
\hline$\Delta \mathrm{LNT3}(\mathrm{ng} / \mathrm{dL})$ & -46.6 & 17.1 & $0.007 *$ & 23.6 & 13.4 & 0.077 \\
\hline$\Delta \mathrm{LNT} 4(\mathrm{ng} / \mathrm{dL})$ & 26.1 & 17.6 & 0.139 & -9.0 & 17.8 & 0.612 \\
\hline
\end{tabular}

$\triangle$ LNTCP model controlled for gender, stress $(\mathrm{y} / \mathrm{n})$ and triglyceride level; TDEP = DEP + DETP; $\triangle$ LNTDEP controlled for gender, education, smoking $(\mathrm{y} / \mathrm{n})$, stress $(\mathrm{y} / \mathrm{n})$ and triglyceride; $\Delta=$ Different between the day after-before values; ${ }^{*} F$-test significant at $p<0.05$.

Table 8. Model for change in thyroid hormone levels (logged morning after spraying-logged morning before spraying) as a function of the change in urinary metabolite levels for sprayed insecticide cypermethrin (logged morning after spraying-logged morning before spraying).

\begin{tabular}{|c|c|c|c|c|c|c|c|c|c|}
\hline \multirow{2}{*}{$\Delta$ thyroid Hormone } & \multicolumn{3}{|c|}{$\begin{array}{c}\Delta \mathrm{LN} 3 \mathrm{PBA}^{\mathrm{a}} \\
\text { (nmol/g Creatinine) }\end{array}$} & \multicolumn{3}{|c|}{$\begin{array}{c}\Delta \text { LNcis, trans-DCCA } \\
\text { (nmol/g Creatinine) }\end{array}$} & \multicolumn{3}{|c|}{$\begin{array}{c}\Delta \text { LNTCyper }{ }^{\mathrm{c}} \\
\text { (nmol/g Creatinine) }\end{array}$} \\
\hline & B & Standard Error & $p$-Value & B & Standard Error & $p$-Value & B & Standard Error & $p$-Value \\
\hline$\Delta \mathrm{LNTSH}(\mathrm{nIU} / \mathrm{mL})$ & 43.2 & 88.9 & 0.627 & 47.9 & 56.6 & 0.397 & 65.8 & 94.7 & 0.487 \\
\hline$\Delta \mathrm{LNFT3}(\mathrm{pg} / \mathrm{dL})$ & 24.3 & 18.3 & 0.185 & 26.4 & 17.1 & 0.122 & 35.1 & 19.2 & 0.067 \\
\hline$\Delta \mathrm{LNFT} 4(\mathrm{pg} / \mathrm{dL})$ & 2.7 & 28.8 & 0.925 & 13.6 & 22.2 & 0.539 & 11.7 & 32.5 & 0.718 \\
\hline$\Delta \mathrm{LNT3}(\mathrm{ng} / \mathrm{dL})$ & -4.1 & 41.7 & 0.921 & 17.7 & 25.8 & 0.492 & 4.3 & 46.3 & 0.926 \\
\hline$\Delta \mathrm{LNT} 4(\mathrm{ng} / \mathrm{dL})$ & -18.1 & 22.9 & 0.431 & 34.8 & 17.5 & $0.046^{*}$ & -1.1 & 22.5 & 0.962 \\
\hline
\end{tabular}

${ }^{a, c}$ Control for gender, stress (y/n), education level and triglyceride level; ${ }^{b}$ Control for age, gender, stress $(\mathrm{y} / \mathrm{n})$, education level and triglyceride level; TCyper = 3PBA + DCCA; $\Delta=$ Different between the day after-before values; ${ }^{*} F$-test significant at $p<0.05$.

Table 9. Model for change in thyroid hormone levels (logged morning after spraying-logged morning before spraying) as a function of the change in urinary metabolite levels for sprayed herbicides paraquat or glyphosate (logged morning after spraying-logged morning before spraying).

\begin{tabular}{|c|c|c|c|c|c|c|}
\hline \multirow{2}{*}{$\Delta$ thyroid Hormone } & \multicolumn{3}{|c|}{$\begin{array}{c}\Delta \mathrm{LNparaquat}{ }^{\mathrm{a}} \\
\text { ( } \mu \mathrm{g} / \mathrm{g} \text { Creatinine) }\end{array}$} & \multicolumn{3}{|c|}{$\begin{array}{l}\Delta \text { LNglyphosate } \\
\text { ( } \mu \text { g/g Creatinine) }\end{array}$} \\
\hline & B & Standard Error & $p$-Value & B & Standard Error & $p$-Value \\
\hline$\triangle \mathrm{LNTSH}(\mathrm{nIU} / \mathrm{mL})$ & 29.5 & 60.6 & 0.627 & 68.1 & 51.1 & 0.183 \\
\hline$\Delta \mathrm{LNFT3}(\mathrm{pg} / \mathrm{dL})$ & -30.0 & 14.3 & $0.036 *$ & 1.7 & 12.1 & 0.888 \\
\hline$\Delta \mathrm{LNFT} 4(\mathrm{pg} / \mathrm{dL})$ & -7.0 & 10.2 & 0.493 & 11.1 & 10.9 & 0.311 \\
\hline$\Delta \mathrm{LNT3}(\mathrm{ng} / \mathrm{dL})$ & -38.1 & 18.2 & $0.036 *$ & 11.7 & 25.1 & 0.642 \\
\hline$\Delta \mathrm{LNT} 4(\mathrm{ng} / \mathrm{dL})$ & 9.4 & 15.4 & 0.539 & 24.5 & 12.2 & $0.045^{*}$ \\
\hline
\end{tabular}

${ }^{a}$ controlled for gender, debt $(\mathrm{y} / \mathrm{n})$, current smoking $(\mathrm{y} / \mathrm{n}) ;{ }^{\mathrm{b}}$ controlled for gender; $\Delta=$ Different between the day-before values; ${ }^{*} F$-test significant at $p<0.05$.

\section{Discussion}

The average age of farmers was almost 50 years of age and over half (54\%) graduated from high school. Most of them were male (74\%). Pesticide spraying was performed using a backpack sprayer which can weigh over 25 pounds before filling with pesticide solution. This may have led to largely male participants in this study. Farmers in Lao, Cambodia and Vietnam, were also mostly male and fewer had graduated from high school (29\%), although they were generally of a similar age as the Thai farmers (averaging 45 years old for Lao and Cambodia and 50 for Vietnam) [48]. In this study, $19.2 \%$ of the farmers smoked 
and $66.7 \%$ drank alcoholic beverages, which is less than that reported for tobacco farmers in Brazil, $29.4 \%$ of whom smoked and $81.8 \%$ of whom drank alcohol if male. [49].

\subsection{Changes in Urinary Pesticide Levels after Spraying}

The GM of the urinary metabolite for chlorpyrifos (TCP) showed a significant increase from pre-spraying to after the spraying event and also the next morning after spraying. This suggests that chlorpyrifos is metabolized quickly, but because the half-life of TCP is $\sim 27 \mathrm{~h}[50,51]$, it is still found in urine the next day. The TCP levels reported here for the day after spraying (GM $14.1 \mathrm{ug} / \mathrm{g}$ creatinine) are lower than a study in Vietnam that found a median urinary TCP of $45.7 \mu \mathrm{g} / \mathrm{g}$ creatinine $24 \mathrm{~h}$ after pesticide application [52]. We believe this is due to the shorter duration of spraying in the current study (average $38 \mathrm{~min}$ with range 7-120 $\mathrm{min}$ ) compared to $5.2 \mathrm{~h}$ (range $3-7.5 \mathrm{~h}$ ) in the Vietnamese study using similar motorized backpack spraying equipment. With regards to non-specific organophosphate (OP) metabolites of chlorpyrifos, the GM of TDEP was increased non-significantly from $458 \mathrm{nmole} / \mathrm{g}$ creatinine on the pre-spraying day to $541 \mathrm{nmole} / \mathrm{g}$ creatinine on the day after spraying. The elimination half-life of organophosphates was $15.5 \mathrm{~h}$ with oral route and $30 \mathrm{~h}$ with dermal route, so it is possible that metabolism to the non-specific metabolites was still occurring and if measurements were made later on in the day after spraying levels would have been significantly higher than the pre-spraying day [53].

All urinary Tcyper, 3PBA and DCCA levels at the end of spraying event were significantly increased from the pre-spraying day, but they were not significantly different with the next day after spraying. This may be due to the short elimination half-life of 3BPA (5.7 h) and DCCA (4.5-5.4 h) [54]. For cypermethrin-spraying farmers, the urinary 3PBA and DCCA are not specific metabolites for cypermethrin, so pre-spraying samples may reflect wider use of pyrethroids. All farmers used insecticides in their home and most of the insecticides used at home contained pyrethroid $[54,55]$. The 3PBA is a metabolite of cypermethrin as well as cyhalothrin, deltamethrin, esfenvalerate, fenpropathrin, permethrin, phenothrin [56]. The DCCA is a metabolite of cypermethrin as well as cyfluthrin and permethrin [56]. Panuwet et al. (2004) [57] reported no significant difference of urinary Tcyper, 3PBA and DCCA levels in four groups of farmers including cut-flower, vegetable, cutflower and vegetable, pesticide free crop, since farmers who applied pesticide to their crops and farmers who did not were equally exposed to cypermethrin, permethrin, cyfluthrin and other pyrethroids.

The detection frequency of urinary paraquat was $62.7 \%$ on the day before spraying, $94.1 \%$ after the spraying event and $76.5 \%$ in the morning after spraying. This was similar to the pattern seen in a study by Lee et al. (2009) [58], showing the detection frequency was $16.2 \%, 52.9 \%$ and $36.1 \%$ on the before-spraying day, on the spray day and the next day. We found a significant increase in paraquat levels from pre-spraying to after the spray event, which may reflect the quick distribution half-life of paraquat (5 h) [59]. However, we also saw a significant drop in the paraquat levels from after spraying till the next morning which was not expected due to paraquat's slow elimination half-life of $84 \mathrm{~h}$ [59]. This current study may have found levels of urinary paraquat on the day before spraying day because sugarcane farmers work in their fields almost every day and may be exposed to paraquat through their agricultural activities, since paraquat has a long half-life in soil (up to 20 years) [31,60].

For urinary glyphosate, we found urinary glyphosate in $100 \%$ of urine samples collected. Acquavella et al. (2004) [61], detected a lower percentage of detectable urinary glyphosate in U.S. farmers on the pre-spraying day, spraying day and day after spraying, 15,60 and $48 \%$ respectively. The high detectable levels pre-spraying may be due to the intensive use of glyphosate resulting in contamination of the environment. The half-life of glyphosate in soil is few days to two or three months [62]. In our study, the GM of urinary glyphosate increased significantly from pre-spraying to after spraying but the next morning, although higher, was it not significantly different from the end of spraying concentration. This may be attributable to the short elimination half-life of glyphosate; 4 and $17 \mathrm{hr}$ in 
male and female [63]. Connolly et al. [63] found that the GM of urinary glyphosate on the day of spraying $(1.2 \mu \mathrm{g} / \mathrm{L})$ was significantly higher than that on the pre-spraying day $(0.7 \mu \mathrm{g} / \mathrm{L})$, but the GM of urinary glyphosate on the next day after spraying $(0.8 \mu \mathrm{g} / \mathrm{L})$ was not significantly higher than that on the pre-spraying day. In addition, in the Connolly et al. (2018) [64] study, the sprayers wore coverall suits, full-face respirators and gloves.

\subsection{Changes in Thyroid Hormone Levels after Spraying}

We found that the simple paired analysis of FT4 was significantly higher the morning after spraying chlorpyrifos and that FT3 increased with borderline significance. However, in models of thyroid level change that incorporated the measured change in metabolite levels and covariates, we found that an increase of one $\mu \mathrm{g} / \mathrm{g}$ creatinine urinary TCP from before to after spraying significantly reduced the thyroid hormone levels of FT3 and T3 in the sprayers. We could not find research with a similar study design, but a study in the freshwater fish $H$. fossilis showed that exposure to $0.284 \mathrm{ppm}$ chlorpyrifos for 30 days decreased serum T3, T4 and TSH significantly compared to the normal control group [65]. A study in rats found no statistically significant change in TSH, but a significant decrease in $\mathrm{T} 3$ and $\mathrm{T} 4$ among rats treated orally $(6.75 \mathrm{mg} / \mathrm{kg})$ for 30 days with chlorpyrifos, compared to the control group [66]. In models that incorporated the measured change in metabolite levels and covariates, we did not find a significant relationship for TDEP. However, a study of chronic DEP exposure of rats compared with a control group resulted in a significant decrease in serum TSH and FT3, but T3 and FT4 levels increased significantly in a dosedependent manner [7].

The current study found that for those spraying cypermethrin, there were no significant changes in the simple paired analysis of thyroid hormone levels before and the morning after spraying. However, in models of thyroid level change that incorporated the measured change in metabolite levels and covariates, we found that an increase in DCCA was associated with a significant increase in T4. Zhang et al. (2013) [24] found that 3-PBA was not a significant predictor of serum thyroid hormones, FT4 and TSH and thyroid binding globulin in pregnant women. Male rats exposed to the pyrethroid fenvalerate $(100-200 \mathrm{mg} / \mathrm{kg}$ ) had significantly increased circulating thyroid hormone levels of T3 and T4. In lizards orally exposed to the pyrethroid lambda-cyhalothrin (LCT) for 21 days, both thyroid hormones, T3 and T4 were significantly increased compared to the control group [67]. When embryonic zebrafish were exposed to the pyrethroids bifenthrin or $\lambda$-cyhalothrin for $72 \mathrm{~h}$; $\mathrm{T} 4$ hormone was significantly decreased while T3 hormone was significantly increased in the bifenthrin exposed group, whereas both T4 and T3 levels were significantly increased in the $\lambda$-cyhalothrin exposed group [68]. However, a human study of 18 workers exposed to pyrethroids in a pyrethroid insecticide manufacturing company found significantly reduced T3 and T4 and increased TSH in exposed workers compared to the control group [69], and a study of Brazilian agricultural workers who reported recent use of lambda-cyhalothrin (pyrethroid) had reduced total T4 [33].

This study did not find any significant change in the simple paired analysis of thyroid hormone levels from the day before to the day after spraying paraquat. However, in models of thyroid level change that incorporated the measured change in metabolite levels and covariates, we found that an increase in urinary paraquat from the day before to the day after spraying significantly reduced the T3 and FT3 hormones. For paraquat, US based studies found an association between ever use of paraquat and risk of hypothyroidism in women but not men [10,11]. Recent use of paraquat among Brazilian agricultural workers was associated with reduced FT3 [33].

For glyphosate spraying, we did not find any significant change in the simple paired analysis of thyroid hormone levels from the day before to the day after spraying. However, in models of thyroid level change that incorporated the measured change in metabolite levels and covariates, we found that an increase in urinary glyphosate from the day before to the day after spraying significantly increased the T4 hormone levels. A study of male offspring of pregnant Wistar rats exposed to glyphosate from gestation day 18 to post-natal 
day 5 found that at post-natal day 90, the offspring showed decreased TSH and no change in T3 and T4 compared to the control groups [70]. A cohort study of licensed pesticide applicators in North Carolina and Iowa with 35,150 participants showed that self-reported use of glyphosate was associated with increased risk of hypothyroidism [9] but it was not consistent with results reported by Goldner et al. (2013) [11] and Lerro et al. (2018) [29].

The findings of the simple paired analysis of thyroid hormone samples taken the morning before spraying and the next morning after spraying in some cases suggested changes in hormone levels in different directions (increasing vs decreasing) when compared to the results of the models that looked at change in hormone levels as a function of change in the measured change in pesticide metabolite levels. This could be because the models, that use metabolite levels, account for differences in the amount and length of spraying as well as use of personal protective equipment to limit exposure and personal hygiene practices to reduce dermal uptake. The simple before and after comparisons do not account for these differences or any individual differences in the ability to metabolize and excrete these pesticides. For example, polymorphisms in the genotype of PON-1, an enzyme that metabolizes OP pesticides, have been shown to directly impact susceptibility to OP toxicity [71]. In addition, unlike the simple paired comparison, the models adjusted for the impact of other potential confounders and covariates such as age, gender, smoking, stress etc.

Limitations of this study include the chronic pesticide exposures experienced by this cohort, which included farmers that have been working with and exposed to pesticides for many years (average 25 years (SD 14.4 years) and do not represent a naïve population for this acute exposure study. In addition, in the case of the cypermethrin sprayers, some of the exposures may have come from home where pyrethroid insecticides are widely used.

Nevertheless, this study is novel in that it examined whether acute exposures to pesticides is associated with acute changes in thyroid hormone levels by measuring pesticide metabolites and thyroid hormones over a 2-day period before and after farmers sprayed the targeted pesticides. Previous studies have focused on the chronic effects on the thyroid using a cross-sectional or longitudinal design using an un-exposed control group for comparison or looking an individual change over time (typically the growing season). The finding that acute exposures can acutely alter thyroid hormone levels suggests a mechanism for the development of chronic HPT axis disruption.

\section{Conclusions}

In studies of more chronic human exposures to pesticides, there is growing evidence that some pesticides can act as endocrine disrupters, altering hypothalamic-pituitarythyroid (HPT) axis hormone levels. However, it was not clear if this disruption from chronic and repeated exposures can also be seen with acute exposures. This paper demonstrates that increases of specific pesticide metabolites from the morning before spraying to the morning after spraying are associated with concurrent changes in hormone levels. A one $\mu \mathrm{g} / \mathrm{g}$ creatinine increase in urinary TCP significantly decreases FT3 and T3 across the same time period; a one-unit increase in urinary cis, trans-DCCS significantly increases T4. For herbicide spraying, the increase in one unit of urinary paraquat from the morning before to the morning after spraying significantly reduceds FT3 and T3, and the increase in one unit of urinary glyphosate significantly increased T4. These findings suggest that repeated acute exposures to pesticides could result in chronic disequilibrium of the HPT axis which may lead to associated metabolic disorders.

Author Contributions: Conceptualization, P.K. (Pornpimol Kongtip), N.N. and S.W.; methodology, P.K. (Pajaree Konthonbut), P.S., J.C. and R.P.; validation, S.P., N.C. and P.K. (Phanthawee Khangkhun); urine and blood analysis, J.Y., C.P. and S.P.; data curation, N.K. and P.K. (Pornpimol Kongtip); writing-original draft preparation, P.K. (Pornpimol Kongtip); writing—review and editing, S.W.; supervision, N.N. and S.W.; project administration, N.N. and N.K.; funding acquisition, P.K. (Pornpimol Kongtip) and S.W. All authors have read and agreed to the published version of the manuscript. 
Funding: This research was financially supported by NIH the Fogarty International Center, National Institutes of Environmental Health Science and the Center for Disease Control under Award Numbers U01 TW0010091 and U2R TW0010088.

Institutional Review Board Statement: The study was conducted according to the guidelines of the Declaration of Helsinki, and approved by the Institutional Review Board (or Ethics Committee) of Faculty of Public Health, Mahidol University (protocol code MUPH 2015-146 and date of approval, 28 August 2015).

Informed Consent Statement: Informed consent was obtained from all subjects involved in the study.

Data Availability Statement: The data presented in this study are available on request from the corresponding author. The data are not publicly available due to privacy of subjects.

Acknowledgments: We would also like to thank the Center of Excellence on Environmental Health and Toxicology (EHT) for laboratory equipment, and all the participants and health-promoting hospital staff in Nakornsawan Province and Rebecca Gore of UMass Lowell for statistical consultation.

Conflicts of Interest: The authors declare no conflict of interest. The funders had no role in the design of the study; in the collection, analyses, or interpretation of data; in the writing of the manuscript, or in the decision to publish the results.

\section{References}

1. Mnif, W.; Hassine, A.I.H.; Bouaziz, A.; Bartegi, A.; Thomas, O.; Roig, B. Effect of endocrine disruptor pesticides: A review. Int. J. Environ. Res. Public Health 2011, 8, 2265-2303. [CrossRef] [PubMed]

2. McKinlay, R.; Plant, J.A.; Bell, J.N.B.; Voulvoulis, N. Endocrine disrupting pesticides: Implications for risk assessment. Environ. Int. 2008, 34, 168-183. [CrossRef] [PubMed]

3. Calsolaro, V.; Pasqualetti, G.; Niccolai, F.; Caraccio, N.; Monzani, F. Thyroid disrupting chemicals. Int. J. Mol. Sci. 2017, 18, 2583. [CrossRef] [PubMed]

4. Boas, M.; Feldt-rasmussen, U.; Mai, K.M. Thyroid effects of endocrine disrupting chemicals. Mol. Cell. Endocrinol. 2012, 355, 240-248. [CrossRef]

5. Crofton, K.M.; Foss, J.A.; Hass, U.; Jensen, K.F.; Levin, E.D.; Parker, S.P. Undertaking positive control studies as part of developmental neurotoxicity testing: A report from the ILSI Research Foundation/Risk Science Institute expert working group on neurodevelopmental endpoints. Neurotoxicol. Teratol. 2008, 30, 266-287. [CrossRef]

6. Diamanti-Kandarakis, E.; Bourguignon, J.P.; Giudice, L.C.; Hauser, R.; Prins, G.S.; Soto, A.M.; Zoeller, R.T.; Gore, A.C. Endocrinedisrupting chemicals: An Endocrine Society scientific statement. Endocr. Rev. 2009, 30, 293-342. [CrossRef]

7. Yang, F.W.; Zhao, G.P.; Ren, F.Z.; Pang, G.; Li, Y.X. Assessment of the endocrine-disrupting effects of diethyl phosphate, a nonspecific metabolite of organophosphorus pesticides, by in vivo and in silico approaches. Environ. Int. 2020, 135, 105383. [CrossRef]

8. Huang, H.-S.; Lee, K.-W.; Ho, C.-H.; Hsu, C.-C.; Su, S.-B.; Wang, J.-J.; Lin, H.-J.; Huang, C.-C. Increased risk for hypothyroidism after anticholinesterase pesticide poisoning: A nationwide population-based study. Endocrine 2017, 57, 436-444. [CrossRef]

9. Shrestha, S.; Parks, C.G.; Goldner, W.S.; Kamel, F.; Umbach, D.M.; Ward, M.H.; Lerro, C.C.; Koutros, S.; Hofmann, J.N.; Freeman, L.E.B.; et al. Pesticide use and incident hypothyroidism in pesticide applicators in the Agricultural Health Study. Environ. Health Perspect. 2018, 126, 97008. [CrossRef]

10. Goldner, W.S.; Sandler, D.P.; Yu, F.; Hoppin, J.A.; Kamel, F.; Levan, T.D. Pesticide use and thyroid disease among women in the Agricultural Health Study. Am. J. Epidemiol. 2010, 171, 455-464. [CrossRef]

11. Goldner, W.S.; Sandler, D.P.; Yu, F.; Shostrom, V.; Hoppin, J.A.; Kamel, F.; Levan, T.D. Hypothyroidism and pesticide use among male private pesticide applicators in the Agricultural Health Study. J. Occup. Environ. Med. 2013, 55, 1171-1178. [CrossRef] [PubMed]

12. Kongtip, P.; Nankongnab, N.; Kallayanatham, N.; Pundee, R.; Choochouy, N.; Yimsabai, J.; Woskie, S. Thyroid hormones in conventional and organic farmers in Thailand. Int. J. Environ. Res. Public Health 2019, 16, 2704. [CrossRef] [PubMed]

13. Nankongnab, N.; Kongtip, P.; Kallayanatham, N.; Pundee, R.; Yimsabai, J.; Woskie, S. Longitudinal study of thyroid hormones between conventional and organic farmers in Thailand. Toxics 2020, 8, 82. [CrossRef]

14. Lacasaña, M.; López-Flores, I.; Rodríguez-Barranco, M.; Aguilar-Garduño, C.; Blanco-Muñoz, J.; Pérez-Méndez, O.; Gamboa, R.; Bassol, S.; Cebrian, M.E. Association between organophosphate pesticides exposure and thyroid hormones in floriculture workers. Toxicol. Appl. Pharmacol. 2010, 243, 19-26. [CrossRef] [PubMed]

15. Satar, S.; Satar, D.; Kirim, S.; Leventerler, H. Effects of acute organophosphate poisoning on thyroid hormones in rats. Am. J. Ther. 2005, 12, 238-242. [CrossRef]

16. Liu, P.; Song, X.; Yuan, W.; Wen, W.; Wu, X.; Li, J.; Chen, X. Effects of cypermethrin and methyl parathion mixtures on hormone levels and immune functions in Wistar rats. Arch. Toxicol. 2006, 80, 449-457. [CrossRef] 
17. Bicker, W.; Lammerhofer, M.; Lindner, W. Determination of chlorpyrifos metabolites in human urine by reversed-phase/weak anion exchange liquid chromatography-electrospray ionisation-tandem mass spectrometry. J. Chromatogr. B 2005, 822, 160-169. [CrossRef]

18. Eaton, D.L.; Daroff, R.B.; Autrup, H.; Bridges, J.; Buffler, P.; Costa, L.G.; Coyle, J.; McKhann, G.; Mobley, W.C.; Nadel, L.; et al. Review of the toxicology of chlorpyrifos with an emphasis on human exposure and neurodevelopment. Crit. Rev. Toxicol. 2008, S2, 1-125. [CrossRef]

19. Sanchez-Fortun, S.; Barahona, M.V. Comparative study on the environmental risk induced by several pyrethroids in estuarine and freshwater invertebrate organisms. Chemosphere 2005, 59, 553-559. [CrossRef]

20. Julien, R.; Adamkiewicz, G.; Levy, J.I.; Bennett, D.; Nishioka, M.; Spengler, J.D. Pesticide loadings of select organophosphate and pyrethroid pesticides in urban public housing. J. Expo. Sci. Environ. Epidemiol. 2008, 18, 167-174. [CrossRef]

21. Sharma, A.; Yadav, B.; Rohatgi, S.; Yadav, B. Cypermethrin Toxicity: A Review. J. Forensic. Sci. Crim. Investig. 2018,9 , 555767.

22. Sharma, P.; Firdous, S.; Singh, R. Neurotoxic effect of cypermethrin and protective role of resveratrol in Wistar rats. Int. J. Nutr. Pharmacol. Neurol. Dis. 2014, 4, 104-111.

23. Sun, H.; Xu, X.L.; Xu, L.C.; Song, L.; Hong, X.; Chen, J.F.; Cui, L.B.; Wang, X.R. Antiandrogenic activity of pyrethroid pesticides and their metabolite in reporter gene assay. Chemosphere 2007, 66, 474-479. [CrossRef] [PubMed]

24. Zhang, J.; Hisada, A.; Yoshinaga, J.; Shiraishi, H.; Shimodaira, K.; Okai, T.; Noda, Y.; Shirakawa, M.; Kato, N. Exposure to pyrethroids insecticides and serum levels of thyroid-related measures in pregnant women. Environ. Res. 2013, 127, 16-21. [CrossRef]

25. Manna, S.; Bhattacharyya, D.; Mandal, T.K.; Dey, S. Neuropharmacological effects of alfa-cypermethrin in rats. Indian J. Pharmacol. 2005, 37, 18-20. [CrossRef]

26. Simescu, M.; Igna, C.P.; Nicolaescu, E.; Ion, I.; Ion, A.C.; Caragheorgheopol, A.; Neagu, C.; Negru, M.; Pribu, M.; Kochanskadziurowicz, A.; et al. Multiple pesticide exposure of greenhouse workers and thyroid parameters. Int. J. Sus. Dev. Plan. 2014, 9, 15-28. [CrossRef]

27. Vivancos, P.D.; Driscoll, S.P.; Bulman, C.A.; Ying, L.; Emami, K.; Treumann, A.; Mauve, C.; Noctor, G.; Foyer, C.H. Perturbations of amino acid metabolism associated with glyphosate-dependent inhibition of shikimic acid metabolism affect cellular redox homeostasis and alter the abundance of proteins involved in photosynthesis and photorespiration. Plant Physiol. 2011, 157, 256-268. [CrossRef]

28. Roberts, D.M.; Buckley, N.A.; Mohamed, F.; Eddleston, M.; Goldstein, D.A.; Mehrsheikh, A.; Bleeke, M.S.; Dawson, A.H. A prospective observational study of the clinical toxicology of glyphosate-containing herbicides in adults with acute selfpoisoning. Clin. Toxicol. 2010, 48, 129-136. [CrossRef]

29. Lerro, C.C.; Koutros, S.; Andreotti, G.; Friesen, M.C.; Alavanja, M.C.; Blair, A.; Hoppin, J.A.; Sandler, D.P.; Lubin, J.H.; Ma, X.; et al. Organophosphate insecticide use and cancer incidence among spouses of pesticide applicators in the Agricultural Health Study. Occup. Environ. Med. 2015, 72, 736-744. [CrossRef]

30. Gawarammana, I.B.; Buckley, N.A. Medical management of paraquat ingestion. Br. J. Clin. Pharmacol. 2011, 72, 745-757. [CrossRef]

31. Watts, M. Paraquat. Available online: http://wssroc.agron.ntu.edu.tw/note/Paraquat.pdf (accessed on 15 November 2020).

32. Government of Thailand. Ministry of Industry Notification, B.E. 2563 (2020) re: List of Hazardous Substances (Issue No. 6) [in Thai]. R. Gaz. 2020, 137, 117.

33. Santos, R.; Piccoli, C.; Cremonese, C.; Freire, C. Thyroid and reproductive hormones in relation to pesticide use in an agricultural population in Southern Brazil. Environ. Res. 2019, 173, 221-231. [CrossRef] [PubMed]

34. Franceschi, C.; Ostan, R.; Stefano Mariotti, S.; Monti, D.; Vitale, G. The aging thyroid: A reappraisal within the geroscience integrated perspective. Endocr. Rev. 2019, 40, 1250-1270. [CrossRef] [PubMed]

35. Ostan, R.; Monti, D.; Mari, D.; Arosio, B.; Gentilini, D.; Ferri, E.; Passarino, G.; De Rango, F.; D'Aquila, P.; Mariotti, S. Heterogeneity of thyroid function and impact of peripheral thyroxine deiodination in centenarians and semi-supercentenarians: Association with functional status and mortality. J. Gerontol. A Biol. Sci. Med. Sci. 2019, 74, 802-810. [CrossRef]

36. Kongtip, P.; Nankongnab, N.; Tipayamongkholgul, M.; Bunngamchairat, A.; Pataitiemthong, A.; Woskie, S. A cross-sectional investigation of cardiovascular and metabolic biomarkers among conventional and organic farmers in Thailand. Int. J. Environ. Res. Public Health 2018, 15, 2590. [CrossRef]

37. Kongtip, P.; Nankongnab, N.; Kallayanatham, N.; Pundee, R.; Yimsabai, J.; Woskie, S. Longitudinal Study of Metabolic Biomarkers among Conventional and Organic Farmers in Thailand. Int. J. Environ. Res. Public Health 2020, 17, 4178. [CrossRef]

38. Kumar, C.R. A study of serum thyroid hormones in organophosphorus compounds poisoning patients. Int. J. Clin. Biochem. Res. 2020, 7, 272-275. [CrossRef]

39. Buranasatitnon, S.; Kongtip, P.; Nankongnab, N.; Tipayamongkholgul, M.; Cheepsattayakorn, A.; Bunkerd, B. Urinary chlorpyrifos metabolite concentrations and chlorpyrifos use behaviors among occupational sprayers in Suphan Buri Province [in Thai]. Dis. Control J. 2020, 26, 473-482.

40. Prapamontol, T.; Sutan, K.; Laoyang, S.; Hongsibsong, S.; Lee, G.; Yano, Y.; Hunter, R.E.; Ryan, P.B.; Barr, D.B.; Panuwet, P. Cross validation of gas chromatographyflame photometric detection and gas chromatography-mass spectrometry methods for measuring dialkylphosphate metabolites of organophosphate pesticides in human urine. Int. J. Hyg. Environ. Health 2014, 217, 554-566. [CrossRef] 
41. Singleton, S.T.; Lein, P.J.; Farahat, F.M.; Farahat, T.; Bonner, M.R.; Knaak, J.B.; Olson, J.R. Characterization of $\alpha$-cypermethrin Exposure in Egyptian Agricultural Workers. Int. J. Hyg. Environ. Health 2014, 217, 538-545. [CrossRef]

42. Konthonbut, P.; Kongtip, P.; Nankongnab, N.; Tipayamongkholgul, M.; Yoosook, W.; Woskie, W. Paraquat Exposure of Pregnant Women and Neonates in Agricultural Areas in Thailand. Int. J. Environ. Res. Public Health 2018, 15, 1163. [CrossRef] [PubMed]

43. Bootsikeaw, S.; Kongtip, P.; Nankongnab, N.; Chantanakul, S.; Sujirarat, D.; Mahaboonpeeti, R.; Khangkhun, P.; Woskie, S. Urinary glyphosate biomonitoring of sprayers in vegetable farm in Thailand. Hum. Ecol. Risk Assess. Int. J. 2020. [CrossRef]

44. Hornung, R.W.; Reed, L.D. Estimation of average concentration in the presence of nondetectable values. Appl. Occup. Environ. Hyg. 1990, 5, 46-51. [CrossRef]

45. Beckmann Coulter, Instruction for Use. Creatinine. Available online: https://www.beckmancoulter.com/wsrportal/techdocs? docname $=/$ cis $/$ A69463/\%\%/EN (accessed on 15 November 2020).

46. Zaidi, S.S.; Bhatnagar, V.K.; Gandhi, S.J.; Shah, M.P.; Kulkarni, P.K.; Saiyed, H.N. Assessment of thyroid function in pesticide formulators. Hum. Exp. Toxicol. 2000, 19, 497-501. [CrossRef]

47. Campos, É.; Freire, C. Exposure to non-persistent pesticides and thyroid function: A systematic review of epidemiological evidence. Int. J. Hyg. Environ. Health 2016, 219, 481-497. [CrossRef]

48. Schreinemachers, P.; Chen, H.; Nguyen, T.T.L.; Buntong, B.; Bouapaoe, L.; Gautam, S.; Le, N.T.; Pinn, T.; Vilaysone, P.; Srinivasan, R. Too much to handle? Pesticide dependence of smallholder vegetable farmers in Southeast Asia. Sci. Total Environ. 2017, 593-594, 470-477. [CrossRef]

49. Fávero, J.L.; Meucci, R.D.; Faria, N.M.X.; Fiori, N.S.; Fassa, A.G. Alcohol consumption among tobacco farmers: Prevalence and associated factors. Ciênc. Saúde Coletiva 2018, 23, 871-882. [CrossRef]

50. Nolan, R.J.; Rick, D.L.; Freshour, N.L.; Saunders, J.H. Chlorpyrifos: Pharmacokinetics in human volunteers. Toxicol. Appl. Pharmacol. 1984, 73, 8-15. [CrossRef]

51. Hines, C.J.; Deddens, J.A. Determinants of chlorpyrifos exposures and urinary 3,5,6-trichloro-2-pyridinol levels among termiticide applicators. Ann. Occup. Hyg. 2001, 45, 309-321. [CrossRef]

52. Phung, D.T.; Connell, D.; Miller, G.; Hodge, M.; Patel, R.; Cheng, R.; Abeyewardene, M.; Chu, C. Biological monitoring of chlorpyrifos exposure to rice farmers in Vietnam. Chemosphere 2012, 87, 294-300. [CrossRef]

53. Griffin, P.; Mason, H.; Heywood, K.; Cocker, J. Oral and dermal absorption of chlorpyrifos: A human volunteer study. Occup. Environ. Med. 1999, 56, 10-13. [CrossRef]

54. Ratelle, M.; Côté, J.; Bouchard, M. Toxicokinetics of permethrin biomarkers of exposure in orally exposed volunteers. Toxicol. Lett. 2015, 232, 369-375. [CrossRef] [PubMed]

55. Heudorf, U.; Angerer, J. Metabolites of pyrethroid insecticides in urine specimens: Current exposure in an urban population in Germany. Environ. Health Perspect. 2001, 109, 213-217. [CrossRef] [PubMed]

56. Hung, C.-C.; Simaremare, S.R.S.; Hsieh, C.-J.; Yiin, L.-M. Simultaneous determination of pyrethroid, organophosphate and carbamate metabolites in human urine by gas chromatography-mass spectrometry (GCMS). Appl. Sci. 2019, 9, 879. [CrossRef]

57. Panuwet, P.; Prapamontol, T.; Chantara, S.; Olsson, A.O.; Barr, D.B. A Pilot Survey of Pesticide-Specific Urinary Metabolites among Farmers in Chiang Mai Highland Agricultural Area. CMU J. 2004, 3, 25-34.

58. Lee, K.; Park, E.K.; Stoecklin-Marois, M.; Koivunen, M.E.; Gee, S.J.; Hammock, B.D.; Beckett, L.A.; Schenker, M.B. Occupational paraquat exposure of agricultural workers in large Costa Rican farms. Int. Arch. Occup. Environ. Health 2009, 82, 455-462. [CrossRef]

59. Houzé, P.; Baud, F.J.; Mouy, R.; Bismuth, C.; Bourdon, R.; Scherrmann, J.M. Toxicokinetics of paraquat in humans. Hum. Exp. Toxicol. 1990, 9, 5-12. [CrossRef]

60. Kongtip, P.; Nankongnab, N.; Phupancharoensuk, R.; Palarach, C.; Sujirarat, D.; Sangprasert, S.; Sermsuk, M.; Sawattrakool, N.; Woskie, S.R. Glyphosate and Paraquat in Maternal and Fetal Serums in Thai Women. J. Agromed. 2017, 22, 282-289. [CrossRef]

61. Acquavella, J.F.; Alexander, B.H.; Mandel, J.S.; Gustin, C.; Baker, B.; Chapman, P.; Bleeke, M. Glyphosate biomonitoring for farmers and their families: Results from the Farm Family Exposure Study. Environ. Health Perspect. 2004, 112, 321-326. [CrossRef]

62. Heinonen-Tanski, H. The effect of temperature and liming on the degradation of glyphosate in two artic forest soils. Soil Biol. Biochem. 1989, 21, 313-317. [CrossRef]

63. Connolly, A.; Jones, K.; Basinas, I.; Galea, K.S.; Kenny, L.; McGowan, P.; Coggins, M.A. Exploring the half-life of glyphosate in human urine samples. Int. J. Hyg. Environ. Health 2019, 222, 205-210. [CrossRef] [PubMed]

64. Connolly, A.; Basinas, I.; Jones, K.; Galea, K.S.; Kenny, L.; McGowan, P.; Coggins, M.A. Characterising glyphosate exposures among amenity horticulturists using multiple spot urine samples. Int. J. Hyg. Environ. Health 2018, 221, 1012-1022. [CrossRef] [PubMed]

65. Khatun, N.; Mahanta, R. A Study on the Effect of Chlorpyrifos (20\% EC) on Thyroid Hormones in Freshwater Fish, Heteropneustes fossilis (Bloch.) by using EIA Technique. Sci. Probe 2014, 2, 8-16.

66. Chebab, S.; Mekircha, F.; Leghouchi, E. Potential protective effect of Pistacia lentiscus oil against chlorpyrifos-induced hormonal changes and oxidative damage in ovaries and thyroid of female rats. Biomed. Pharmacother. 2017, 96, 1310-1316. [CrossRef]

67. Chang, J.; Hao, W.; Xu, Y.; Xu, P.; Li, W.; Li, J.; Wang, H. Stereoselective degradation and thyroid endocrine disruption of lambda-cyhalothrin in lizards (Eremias argus) following oral exposure. Environ. Pollut. 2018, 232, 300-309. [CrossRef]

68. Tu, W.; Xu, C.; Lu, B.; Lin, C.; Wu, Y.; Liu, W. Acute exposure to synthetic pyrethroids causes bioconcentration and disruption of the hypothalamus-pituitary-thyroid axis in zebrafish embryos. Sci. Total Environ. 2016, 542, 876-885. [CrossRef] 
69. El-Magd, S.A.A.; Sabik, L.M.E.; Shoukry, A. Pyrethroid Toxic Effects on some Hormonal Profile and Biochemical Markers among Workers in Pyrethroid Insecticides Company. Life Sci. J. 2011, 8, 311-322.

70. de Souza, J.S.; Kizys, M.M.; da Conceicao, R.R.; Glebocki, G.; Romano, R.M.; Ortiga-Carvalho, T.M.; Giannocco, G.; da Silva, I.D.; da Silva, M.R.D.; Romano, M.A.; et al. Perinatal exposure to glyphosate-based herbicide alters the thyrotrophic axis and causes thyroid hormone homeostasis imbalance in male rats. Toxicology 2017, 377, 25-37. [CrossRef]

71. Matthews, A.R.; Sutter, M.E.; Rentz, D.E. Serum paraoxonase-1 (PON-1) genotype and exposure to organophosphorous insectidesIs there a high-risk population? J. Med. Toxicol. 2011, 7, 243-247. [CrossRef] 